\title{
KONFLIKTY O SIRMIUM W DOBIE UPADKU PAŃSTWA OSTROGOTÓW (526-535)
}

\author{
Stanisław Turlej \\ Uniwersytet Jagielloński w Krakowie
}

\section{ABSTRACT \\ CONFLICTS OVER SIRMIUM DURING THE DECLINE OF THE OSTROGOTHIC KINGDOM (526-535)}

Little is known about Sirmium in the period from the death of Theodoric the Great (526) to Justinian's war against the Ostrogoths (535). So far the simplest and most obvious method of analysing the surviving written sources, i.e. literal interpretation, has not been used for reconstructing the history of this city. Instead, for unclear reasons, it is almost commonly accepted that in 530 the city was attacked by the Gepids. The Ostrogoths supposedly repelled the enemy and their future king, Vitiges, distinguished himself in the battle. However, on the basis of the written sources (Cassiodorus and Procopius of Caesarea), a completely different reconstruction of the events is possible. It is more likely that there were two wars for Sirmium between the Gepids and the Ostrogoths: the first one in 526-527 and the second in 533-534. An examination of the historical context confirms that these two conflicts could have been consistent with other events and, just as importantly, enables us to explain the Ostrogoths' complete inactivity in the face of the Frankish invasion.

Key words: Late Antiquity, Byzantium, Ostrogoths, Sirmium, Cassiodorus, Procopius of Caesarea. Słowa kluczowe: późny antyk, Bizancjum, Ostrogoci, Sirmium, Kasjodor, Prokopiusz z Cezarei.

Na początku VI wieku Ostrogoci opanowali Sirmium nad Sawą i okoliczne ziemie rozciągające się do Dunaju ${ }^{1}$. Nabytki w Panonii zdecydowanie wzmocniły ich

1 W latach 473-504 Sirmium należało do Gepidów - W. Poh1, Die Gepiden und die Gentes an der mitteren Donau nach dem Zerfall des Attilareiches [w:] H. Wolfram, F. Daim, Die Völker an der Mitteren und Unteren Donau im Fünften und Sechsten Jahrhundert, Österreichische Akademie der Wissenschaften, Philosophisch-Historische Klasse, Denkschriften 145, Wien 1980, s. 288-292; M. Pańdura, Ardarici gladius. Historia Królestwa Gepidów, „Slavia Antiqua” 2004, XLV, s. 68; A. S a rantis, War and Diplomacy in Pannonia and the Northwest Balkans during the reign of Justinian. The Gepid Threat and Imperial Responses, „Dumbarton Oaks Papers” 2009, 63, s. 15-21. Walki w regionie na początku VI w. na tle późniejszych są stosunkowo nieźle udokumentowane, lecz interpretacje źródeł 
pozycję polityczną i militarną w regionie północno-zachodniego Illyricum, lecz pogorszyły stosunki z Gepidami i przede wszystkim z Bizancjum ${ }^{2}$. Po śmierci Teodoryka Wielkiego w 526 roku doszło do wznowienia walk o Sirmium, o których przebiegu niewiele wiadomo, a ich znaczenie jest zdecydowanie większe, niż mogłoby się wydawać na pierwszy rzut oka. Uporządkowanie skromnych informacji źródłowych na temat losów tego miasta w okresie od 526 roku do uderzenia wojsk Justyniana na Dalmację i Sycylię w 535 roku odgrywa istotną rolę w innej od dotychczasowych rekonstrukcji walk na wschodnich rubieżach państwa Ostrogotów oraz pozwala na pogłębienie ustaleń na temat polityki cesarza Justyniana w stosunku do obszarów naddunajskich ${ }^{3}$.

Punktem wyjścia do odtwarzania konfliktów o Sirmium powinna być najprostsza i najbardziej oczywista metoda analizy zachowanych wzmianek źródłowych poświęconych temu ośrodkowi w latach 526-535, polegająca na ich dosłownej interpretacji i odniesieniu do kontekstu historycznego ${ }^{4}$. Walki o Sirmium bądź o obszary nad Dunajem mające na celu jego opanowanie wspominają tylko dwaj współcześni rozgrywającym się wydarzeniom autorzy: Kasjodor i Prokopiusz z Cezarei. Ich informacje pozbawione są precyzyjnych danych chronologicznych i jakkolwiek niemal zawsze są wspominane w literaturze przedmiotu, to zazwyczaj nie doszukiwano się ich samoistnego znaczenia, traktując je jako epizody, które wkomponowywano do całościowych, wielowątkowych rekonstrukcji poświęconych rywalizacji Ostrogo-

utrudnia ich wymowa propagandowa: J. Prostko-Prostyński, Utraeque Res Publicae. The Emperor Anastasius I’s Gothic Policy (491-518), Poznań 1994, s. 215-245.

2 Ustalenia dotyczące polityki cesarza Anastazjusza w stosunku do Ostrogotów: J. Prostko-Prostyński, op. cit.; F. Haarer, Anastasius I. Politics and Empire in the Later Roman World, Cambridge 2006, s. 91-114; M. Meier, Anastasios I. Die Entstehung des Byzantinischen Reiches, Stuttgart 2009, s. 223-242. Najnowsze ujęcie: A. Sarantis, Justinian's Balkan Wars. Campaigning, Diplomacy and Development in Illyricum, Thrace and the Northern World A.D. 527-565, Prenton 2016, s. 124-135. Istnieje pilna potrzeba uszczegółowienia badań nad sytuacją w Illyricum w ostatnich latach panowania Anastazjusza. Bardzo dużo się wówczas wydarzyło i miało to związek z Ostrogotami S. Turlej, Justyniana Prima. Niedoceniany aspekt polityki kościelnej Justyniana, Kraków 2011, s. 178185; idem, Herulian Settlements in Byzantium under Emperors Anastasius and Justinian, „Electrum” 2013, 20, s. 163-176.

3 Działania podejmowane przez cesarza Justyniana miały jakoby odegrać niebagatelną rolę w procesie kształtowania się etnosu słowiańskiego nad Dunajem: F. Curta, The Making of the Slavs. History and Archaeology of the Lower Danube Region, c. 500-700, Cambridge 2001; idem, Tworzenie Stowian. Powrót do stowiańskiej etnogenezy [w:] Nie-Stowianie o początkach Stowian, red. P. Urbańczyk, Poznań-Warszawa 2006, s. 27-55. Nie wydaje się to przekonujące: S. Turlej, Justynian i poczatki Stowian. Uwagi na temat teorii Florina Curty, „Zeszyty Naukowe Uniwersytetu Jagiellońskiego. Prace Historyczne", z. 137, pod red. A. Patka, 2010, s. 11-19. Najnowsze opracowanie: A. Sarantis, Justinian's..., s. 65-82.

4 Dzieje Sirmium: M. Mirković, Sirmium - its history from the I century A. D. to 582 A.D., Sirmium I: Archaeological Investigations in Syrmian Pannonia, ed. V. Popović, Belgrad 1971, s. 5-90; K. Vössing, Sirmium, „Reallexikon der Germanischen Altertumskunde (RGA)” 2005, 28, s. 499-502. Na temat sytuacji w Panonii w późnym antyku: R. Bratož, Pannonien, „RGA” 2003, 22, s. 469-483; C.D. Caldwell III, The Balkans [w:] The Oxford Handbook of Late Antiquity, Oxford 2012, s. 92114; H. Gračanin, J. Škargulja, The Ostrogoths in the Late Antique Southern Pannonia, „Acta Archaeologica Carpathica” 2014, XLIX, s. 165-205. 
tów, Gepidów i Bizancjum. Takie podejście wymuszało odstępstwa od dosłownej interpretacji źródeł poświęconych Sirmium przy ustalaniu chronologii i przebiegu walk o to miasto ${ }^{5}$. W dotychczasowych badaniach w ogóle nie dostrzegano potrzeby dokonania przed całościową charakterystyką sytuacji na obszarach naddunajskich w latach 526-535 odrębnego opracowania uchwytnych w źródłach szczegółowych, lecz ważnych zagadnień politycznych i militarnych ${ }^{6}$.

Bardzo skromne i ogólne wzmianki zawarte w dziełach Kasjodora, uczonego, z pochodzenia arystokraty rzymskiego i jednocześnie prominentnego urzędnika na dworze w Rawennie, pozwalają odnotować konflikt na wschodniej granicy państwa Ostrogotów po śmierci Teodoryka Wielkiego ${ }^{7}$. W słynnym liście skierowanym do senatu rzymskiego z okazji objęcia stanowiska prefekta pretorium Italii nawiązał on, jak się przyjmuje, w zawoalowanej formie do walk o Sirmium ${ }^{8}$. W swym wystąpie-

5 Przedstawienia walk o Sirmium i regionie w różnych ujęciach: A. Sarantis, Justinian's..., s. 60-65; H. Gračanin, J. Škargulj a, The Ostrogoths..., s. 185; E. Stein, Histoire du Bas-Empire, t. II, Paris-Bruxelles-Amsterdam 1949, s. 305-308; F.E. Wozniak, East Rome, Ravenna and Western Illyricum: 454-536, „Historia” 1981, 30, s. 376-380. Dalsze omówienie literatury w przypisach 24, 25.

6 Obok konfliktu o Sirmium trzy zagadnienia mają szczególne znaczenie dla odtwarzania historii tego okresu: sojusz cesarza Justyniana z Herulami, pozyskanie przez niego wodza Mundusa, związanego wcześniej z Ostrogotami, oraz sukcesy wojsk cesarskich dowodzonych przez Mundusa w walkach z barbarzyńcami nad Dunajem, zwłaszcza z Gepidami. Najnowsze ich przedstawienie: A. Sarantis, Justinian's..., s. 40-60. Jak bardzo brakuje szczegółowej analizy poszczególnych problemów, widać przy porównaniu opracowań: A. S a ranti s, War and Diplomacy..., s. 21-24; idem, Military Encounters \& Diplomatic Affairs in the Northern Balkans [w:] War and Warfare in Late Antiquity. Current perspectives, eds. A. Sarantis, N. Christie, „Late Antique Archaeology” 2011, v. 8.2, Brill, LeidenBoston 2013, s. 767; idem, Justinian 's..., s. 40-65.

Postać i kariera Kasjodora - L.M. Hartmann, Cassiodorus 4 [w:] Realencyclopädie der Classischen Altertumswissenschaft, III, Stuttgart 1899, kol. 1672-1676 (RE); J.R. Martindale, Fl. Magnus Aurelius Cassiodorus Senator 4 [w:] The Prosopography of the Later Roman Empire, vol. II, Cambridge 1980, s. 265-269 (PLRE); S. Krautschick, Cassiodor und die Politik seiner Zeit, Bonn 1983, s. 1-20. Nowsze opracowania: A. Giardina, Cassiodoro politico, Roma 2006, i bardziej ogólne, ukazujące Kasjodora na szerokim tle epoki: F. Cardini, Cassiodoro il Grande. Roma i barbarii e il monachsimo, Milano 2009, s. 71-98; P. Heather, Odrodzenie Rzymu. Cesarze i papieże: bój o władzę nad chrześcijaństwem, przeł. J. Szczepański, Poznań 2014, s. 72-75. Dla badań nad epoką wartość dorobku, zwłaszcza listów Kasjodora, jest duża i trudna momentami do przecenienia, co od dawna po dzień dzisiejszy jest przyznawane: T. Hodgk in, Italy and Her Invaders, Oxford 1896, vol. III, Book IV, s. 291; A. Gillett, Envoys and Political Communication in the Late Antique West, 411-533, Cambridge 2003, s. 176; C. Kakrid i, Cassiodors ,,Variae”. Literatur und Politik im ostrogotischen Italien, Leipzig 2005, s. 157-291. Ciągle aktualna jest dyskusja nad celem i datacją publikacji listów - A. Gillett, The purposes of Cassiodorus' Variae' [w:] After Rome's Fall: Narrators and Sources of Early Medieval History, ed. A. Murray, Toronto 1998, s. 37-50; M.S. Bjornlie, Politics and Tradition between Rome, Ravenna and Constantinople. A Study of Cassiodorus and the Variae, 527-554, Cambridge 2013, s. 1133. Zestawienie najnowszej literatury poświęconej badaniom nad jego spuścizną podaje M.G. Bajoni, À propos d'une lettre diplomatique: Cassiodore, Variae I, 1, „Latomus” 2015, 74, s. 493-497.

8 Senatui Urbis Romae Senator PPO [w:] Cassiodori senatoris variae, ed. Th. Mommsen, Monumenta Germaniae Historica. Auctores Antiquissimi (MGH AA) XII, Berolini 1894, s. 327-330, ewentualnie: Kasjodor Senator, Variae (I-XII), przekład A. Kołtunowska, R. Sawa, rewizja przekładu i opracowanie M. Ożóg, H. Pietras, Kraków 2017, s. 407-412 (dalej Kasjodor, Variae). Ten list otwiera XI księgę zbioru listów Kasjodora. Napisany został w konwencji panegiryku dla Amalasunty. Ze względu na wielowątkową treść jego znaczenie jako źródła jest duże 
niu Kasjodor, zwracając się do senatu, unikał podnoszenia wątku choroby Atalaryka i jego udziału w sprawowaniu władzy, natomiast wychwalał pochodzenie, wykształcenie i politykę Amalasunty ${ }^{9}$. Jako tło do podkreślenia pomyślnych rządów królowej w sferze stosunków z sąsiadami przypomniał i krytycznie omówił działania Galli Placydii ${ }^{10}$. Ta ostatnia była w podobnej sytuacji jak Amalasunta, ponieważ sprawowała opiekę nad synem i rządziła państwem. Według Kasjodora Galla Placydia oddała Konstantynopolowi Illyricum, a przez długotrwały pokój doprowadziła do upadku wojska ${ }^{11}$. Tymczasem Amalasunta prowadziła zręczną politykę, a armia Ostrogotów utrzymała swą siłę:

Sub hac autem domina, quae tot reges habuit quot parentes, iuvante deo, noster exercitus terret externos: qui provida dispositione libratus nec assiduis bellis adteritur nec iterum longa pace mollitur ${ }^{12}$.

Bezpośrednio dla rozważań nad sytuacją Sirmium znaczenie ma cały następny ustęp tekstu, w którym Kasjodor przedstawił sytuację na wschodnich rubieżach państwa Ostrogotów i odniósł się do ich stosunków z cesarzem Justynianem:

in ipsis quoque primordiis, quando semper novitas incerta temptatur, contra Orientis principis votum Romanum fecit esse Danuvium. Notum est quae pertulerint invasores: quae ideo praetermittenda diiudico, ne genius socialis principis verecundiam sustineat perditoris. quid enim de nostris partibus senserit, hinc datur intellegi, quando pacem contulit laesus, quam aliis con-

i bywa bardzo często wykorzystywany przy omawianiu rozmaitych problemów. Całościowy komentarz - V. Fauvinet-Rans on, Portrait d'une regente: un panegyrique d'Amalasonthe (Cassiodorus, Variae XI.1), „Cassiodorus” 1998, 4, s. 267-308; Cassiodoro Variae. Volume 5: Libri XI, XII. Direzione di A. Gardina. A cura di A. Gardina, G. Cecconi e I. Tantillo, Roma 2015, s. 14-21 (tekst), s. 127-152 (komentarz); J.J. Arnold, Theoderic and the Roman Imperial Restoration, Cambridge 2014, s. 48-51; M.S. Bjornlie, op. cit., s. 306-307.

9 Układ materiału w liście: V. F a u vinet-Ran so n, op. cit., s. 276-277, wątek Amalasunty - s. 292 297, 302-303; Cassiodoro Variae..., s. 129. Trudności z rekonstrukcją sytuacji po śmierci Teodoryka M. Vitie1lo, Theodahad: A Platonic King at the Collapse of Ostrogothic Italy, Toronto 2014, s. 59-63. Omówienie rządów Amalasunty: H. Kohl, Zehn Jahre ostgotischer Geschichte, vom Tode Theoderich's des Grossen bis zur Erhebung des Vitigis, Leipzig 1877, s. 1-50; L.M. Hartmann, Geschichte Italiens im Mittelalter, Bd. I, Gotha 1897, s. 229-243; H. Wolfram, Historia Gotów, przeł. R. Darda-Staab, I. Dę bek, K. Berger, Warszawa-Gdańsk 2003, s. 379-387. Kasjodor i Amalasunta - S. Krautschick, op. cit., s. 161-183. Relacja Prokopiusza z Cezarei o Amalasuncie: K. Cooper, The heroine and the historian: Procopius of Caesarea on the troubled reign of Queen Amalasuentha [w:] A Companion to Ostrogothic Italy, eds. J.J. A rnold, M.S. B jornl ie, K. Ses s a, Brill, Leiden-Boston 2016, s. 296-315.

10 Wątek Galli Placydii - V. Fauvinet-Ranson, op. cit., s. 297-301; J.J. Arnold, op. cit., s. 49. Wyraźnie wyodrębniony fragment listu poświęcony jest sytuacji w Illyricum i stosunkom z cesarstwem, a następnie Frankom i Burgundom - Kasjodor, Variae XI, 1, 9-13. Omówienie ówczesnej sytuacji państwa Ostrogotów w Italii, Galii i Illyricum na tle wystąpienia Kasjodora - H. Wolfram, Historia Gotów, s. 382-383.

11 Kasjodor, Variae XI, 1, 9. Problem podporządkowania całego Illyricum przez matkę Walentyniana III Konstantynopolowi budzi dyskusje: F.E. Wozniak, East Rome..., s. 367; J. Prostko-Pros tyńs ki, op. cit., s. 216-219. Omówienie literatury-H. Grača nin, The Huns and South Pannonia, „Byzantinoslavica” 2006, LXIV, s. 54-58.

12 Kasjodor, Variae XI, 1, 10. H. Wolfram, Historia Gotów, s. 380; J.J. Arnold, op. cit., s. 48-49. 
cedere noluit exoratus. additur quod tantis nos legationibus tam raro requisitus ornavit et singularis illa potentia, ut Italicos dominos erigeret, reverentiam Eoi culminis inclinavit ${ }^{13}$.

Powyższa relacja prawie nie zawiera precyzyjnych informacji ani o przebiegu konfliktu w sferze militarnej, ani o szerszym tle politycznym. Pozwala jedynie stwierdzić zaistnienie zwycięskich dla Ostrogotów walk z nienazwanymi agresorami w początkach regencji Amalasunty. Czas rozgrywania się tych wydarzeń został wyraźnie i jednoznacznie wskazany przez użycie sformułowania: ,in ipsis quoque primordiis, quando semper novitas incerta temptatur". W kontekście tej wypowiedzi wyrażenie „contra Orientis principis votum Romanum fecit esse Danuvium” jest odczytywane jako dowód na posiadanie przez Ostrogotów obszarów nad Dunajem wbrew woli cesarza Justyniana ${ }^{14}$. Biorąc pod uwagę położenie geograficzne Sirmium, powyższy zwrot oznacza, że pozostało ono pod ich władzą. Nakreślony przez Kasjodora obraz polityki Justyniana w stosunku do Ostrogotów jawi się jako niespójny, niejasny i sprzeczny w całościowej wymowie. O ile na początku pojawiają się oskarżenia sugerujące, że z perspektywy dworu w Rawennie w jakiś sposób Konstantynopol był zaangażowany w wydarzenia rozgrywające się nad Dunajem, zmierzające do pozbawienia Ostrogotów tych ziem, o tyle kolejne informacje dobitnie świadczą nie tylko o pokojowych stosunkach między obu państwami, lecz wręcz o wyróżnianiu przez cesarza relacji politycznych z władcami Italii.

Brakuje w enigmatycznej wypowiedzi Kasjodora podstawowych i oczywistych dla jego współczesnych informacji o sprawcy ataku na posiadłości Ostrogotów oraz przyczynie oskarżeń pod adresem Justyniana. Jak się wydaje, takie ujęcie sytuacji $\mathrm{w}$ regionie naddunajskim i stosunków z cesarzem mogło być podyktowane względami politycznymi. Najwidoczniej nie można było tego zagadnienia przemilczeć, a równocześnie należało ukazać zdolności królowej do obrony państwa i prowadzenia niezależnej polityki zagranicznej. Biorąc pod uwagę propagandową wymowę tego listu, będącego w istocie panegirykiem na cześć Amalasunty, jak również jego adresatów, czyli nie tylko członków senatu rzymskiego, lecz ogólnie elity polityczne w państwie Ostrogotów, trzeba ostrożnie interpretować ten przekaz przy uwzględnieniu perspektywy chronologicznej, z jakiej pisał Kasjodor. Charakteryzował on bowiem sytuację na wschodniej granicy i stosunki z Justynianem po 1 września 533 roku, kiedy objął urząd prefekta pretorium Italiii ${ }^{15}$. W ciągu siedmiu lat od śmierci Teodoryka Wielkiego sporo się zmieniło na obszarach naddunajskich i - co nie mniej

13 Kasjodor, Variae XI, 1, 10-11. V. Fauvinet-Rans on, op. cit., s. 270, 286-287.

14 Nie ma problemu z identyfikacją „Orientis principi” jako Justyniana: J. Prostko-Prostyński, op. cit., s. 176, przyp. 108, a ,invasores” to prawdopodobnie Gepidzi: V. Fau vinet-Ran son, op. cit., s. 287. Pozostaje jedynie problem, czy Ostrogoci tylko się bronili, czy też zaatakowali, osiągając nabytki terytorialne kosztem cesarstwa. Sporo niejasności w badaniach wywołuje kwestia zakończenia przez Anastazjusza sporu o Panonię i Sirmium z Teodorykiem w związku z potrzebą określenia, jak rozwiązano kwestię przebiegu granicy. W literaturze dominuje rekonstrukcja zaproponowana przez E. Steina, op. cit., s. 156; J. Prostko-Prostyński, op. cit., s. 244; H. Wolfram, Historia Gotów, s. 366. Omawiam to w artykule Sirmium w polityce Justyniana I w „Piotrkowskich Zeszytach Historycznych” 2018.

15 Datacja listu nie jest dokładnie znana, lecz przyjmuje się jego opracowanie niedługo po 1 września 533 r. - M. Vitie1lo, Cassiodorus anti-Boethius?, „Klio”2008, 90, s. 463. Dalsza literatura w przyp. 47. 
ważne - nie było jasne, jaką politykę będzie prowadził Justynian. Ukształtował się nowy system sojuszy i przede wszystkim wzrosła jeszcze bardziej potęga cesarstwa, które jawiło się wówczas jako jedyny beneficjent dokonujących się w regionie naddunajskim bardzo niekorzystnych dla Ostrogotów przemian politycznych i militarnych ${ }^{16}$. Prawdopodobnie właśnie te ostatnie wydarzenia wpłynęły na tak pokrętne i niejasne ujęcie przez Kasjodora opisu samych walk nad Dunajem i stosunków Rawenny z Konstantynopolem. Te ostatnie były zaś pokojowe, a z Amalasuntą - wręcz doskonałe ${ }^{17}$.

Prawdopodobnie w grudniu 536 roku lub na początku 537 roku Kasjodor przygotował mowę pochwalną z okazji małżeństwa Matasunty, córki Amalasunty, z Witigesem $^{18}$. Związek z wnuczką Teodoryka Wielkiego miał wzmocnić pozycję nowego króla Ostrogotów niepochodzącego z dynastii Amalów, stojący lojalnie przy jego boku Kasjodor przypomniał zatem w okolicznościowym utworze jego osiągnięcia. Ze względu na zły stan zachowania tego dzieła, odwołując się do niego, w zasadzie nic pewnego nie możemy powiedzieć o walkach o Sirmium. Do problematyki związanej z konfliktami o ten ośrodek można się odnieść natomiast dzięki wzmiankom o karierze Witigesa. Najważniejsze znaczenie przypisuje się ustępowi, w którym przyszły król został przedstawiony jako spatariusz służący radą Atalarykowi i biorący udział w enigmatycznym wydarzeniu mającym związek z miastem Singidunum ${ }^{19}$ :
[...] spatarii meruisti
nihilominus dignitatem, ut laborem
bellicum honor testaretur armo-
rum. quem locum tua modestia et
maturitatae nobilitans, otioso pro
parvula aetate rege, cum legatis sae-
pius necessaria dissertabas; et mi-
ro laudis eventu reverentiam

16 Kasjodorowi chodziło zapewne, by nie prowokować arystokracji ostrogockiej zbytnią uległością w stosunku do cesarza, bo sytuacja nad Dunajem ciągle była groźna. Z drugiej strony mógł sobie pozwolić na ton krytyczny pod adresem Justyniana, ponieważ jego autorytet ucierpiał po buncie w stolicy, a dopiero zwycięstwo w Afryce odbudowywało jego pozycję i prestiż - M. Meier, Das andere Zeit Justinians, Göttingen 2003, s. 150-165. Przy uwzględnieniu rezultatów analizy okoliczności, w jakich Justynian pozyskał Herulów i Mundusa, wywody Kasjodora nie powinny być traktowane jako dowód na bezpośrednie zaangażowanie się Justyniana przeciw Ostrogotom w walkach o Sirmium. Omawiam to w artykule: Sirmium w polityce Justyniana I.

17 Kasjodor przygotowujący korespondencję dyplomatyczną z Konstantynopolem był zorientowany w sytuacji - A. Gillett, Envoys..., s. 179-180. Zupełnie z innej perspektywy i niezależnie Prokopiusz z Cezarei potwierdza dobre relacje Konstantynopola z Rawenną. Omawiam ten problem w innym artykule: Bizancjum i Ostrogoci za rządów Amalasunty w relacji Prokopiusza z Cezarei.

18 Cassiodori Orationvm Reliqviae, ed. L. Traube, MGH AA XII, s. 473-484 (dalej Kasjodor, Oratio II). Datacja J.R. Martindale, Vitigis, PLRE III b, Cambridge 1992, s. 1382. Ten utwór był znany i łączony z Teodahadem - M. Haupt, Bruchstück einer Lobrede auf den König Theodahad, „Hermes” 1873,7, s. 379.

19 Miasto w prowincji Mezji I u ujścia Sawy do Dunaju, dzisiejszy Belgrad. W okresie późnorzymskim twierdza - F. Barišić, Vizantiski Singidunum, „Zbornik Radova Vizantološkog Instituta” 1953, 3, s. 1-14; V. Dintchev, Classification of the Late Antique cities in the dioceses of Thracia and Dacia, „Archaeologia Bulgarica” 1999, III, s. 47. 
tibi potius impendi feceras, qui seni-

libus curis adulto principi serviebas.

Singidunum civitas quondam otii $* * *^{20}$.

Zwykle przyjmuje się, że wzmianka o Singidunum odnosi się do walk o to miasto prawdopodobnie z Gepidami, w których to walkach wziął udział Witiges ${ }^{21}$. Miały one mieć miejsce na początku panowania Atalaryka - ze względu na sformułowanie określające jego wiek: „parvula aetate rege"22. Uwzględniając panegiryczny charakter utworu i datę jego powstania, gdy Witiges był już królem, wychwalanie jego roli w otoczeniu młodego Atalaryka nie dziwi, pozostaje jednak faktem brak jakiejkolwiek wzmianki wprost mówiącej o roli, jaką odegrał on w walkach prowadzonych prawdopodobnie pod Sirmium z Gepidami.

Reasumując, warto zwrócić uwagę na spójność relacji Kasjodora w obu omawianych dziełach odnośnie do czasu i miejsca walk na wschodnich rubieżach państwa Ostrogotów. W pierwszym utworze odnotowuje on bowiem konflikt na początku regencji Amalasunty, a w drugim - w okresie małoletniości Atalaryka. Prowadzone wówczas działania wojenne pozwoliły utrzymać Ostrogotom ziemie do Dunaju, a więc i Sirmium. $Z$ takim obrazem walk doskonale koresponduje wzmianka o Singidunum, które z względu na położenie miało kluczowe znaczenie dla zabezpieczenia Sirmium $^{23}$. Jak się wydaje, w obu utworach Kasjodor z różnych perspektyw, wychwalając Amalasuntę bądź Witigesa, przedstawia ten sam konflikt, zapoczątkowany niedługo po śmierci Teodoryka Wielkiego w 526 roku $^{24}$. Nic więcej nie można o tej wojnie Ostrogotów nad Dunajem powiedzieć poza tym, że z analizy sytuacji w regionie wynika, iż walczyli z Gepidami. Tymczasem w literaturze rozpowszechniony jest jej sztuczny obraz z wyeksponowanym wątkiem wybitnej roli Witigesa

20 Kasjodor, Oratio II, s. 476, 11-21. Ten przekaz jest traktowany jako dodatkowe świadectwo źródłowe dokumentujące walki na wschodnich granicach państwa Ostrogotów. Wspominali o nim przy omawianiu sporu o Sirmium: E. Stein, Untersuchungen zur spätrömische Verwaltungsgeschichte, „Rheinisches Museum für Philologie” 1925, 74, s. 357; L. Schmidt, Die Ostgermanen, München 1941, s. 534, przyp. 6; E. Stein, Histoire..., s. 308 przyp. 1; J. Prostko-Prostyń ski, op. cit., s. 243.

21 Komentarz wydawcy - Traube, MGH AA XII, s. 463 przyp. 3. Zachowany tekst ma poważne luki i błędy. Jak ograniczone są możliwości analizy, wskazał J.R. Martindale, Vitigis, s. 1382-1383.

22 Kasjodor, Oratio II, s. 476, 16. Informacje źródłowe na temat wieku Atalaryka w chwili śmierci dziadka są rozbieżne: 8 lat według Prokopiusza, a 10 według Jordanesa - omówienie wzmianek: J.R. Martindale, Athalaricus, PLRE II 1980, s. 175-176; H. Wolfram, Historia Gotów, s. 379.

${ }_{23}$ Warto zwrócić uwagę na ujęcie problemu granicy państwa Ostrogotów z cesarstwem przed rozpoczęciem z nimi wojny przez Justyniana. Omawiam to w artykule: Bizancjum i Ostrogoci za rzadów Amalasunty w relacji Prokopiusza z Cezarei.

24 Wojna w latach 526/527 - F. Curta, The Making..., s. 116. Również pojawia się datacja 527/528 F.E. Wozn i ak, Byzantine Diplomacy and the Lombard - Gepidic Wars, „Balkan Studies” 1979, 20, s. 144; idem, East Rome ..., s. 378-379. Przyjmuje się również, że ten atak nastąpił w 528 r. - M. Mirković, op. cit., 51; I. Bón a, Das Anbruch Mittelaters. Gepiden und Langobarden im Karpatenbecken, Budapest 1976, s. 17. Za 529 r. opowiada się J. Prostko-Prostyński, op. cit., s. 242; A. Sarantis, War and Diplomacy..., s. 22 i 23, pisze o walkach w 527 r., by na s. 24 - o klęsce Gepidów w 530 r. Trudno rozeznać się w interpretacji tego autora w świetle kolejnych jego publikacji, lecz prawdopodobnie skłania się do późniejszej - idem, Justinian's..., s. 60-63, również przyp. 6. 
jako dowódcy i z datacją na 530 rok $^{25}$. Nie ma jakiejkolwiek wzmianki źródłowej pozwalającej na przyjęcie takiej chronologii konfliktu o to miasto, w związku z czym posługiwanie się nią mogłoby mieć miejsce tylko wtedy, gdyby wykazano, że dane źródłowe wprost mówiące o tym wydarzeniu są niewiarygodne bądź nie dają jakiejkolwiek szansy na sensowną interpretację w kontekście historycznym. Tymczasem niczego takiego nie zrobiono, lecz pośrednio drogą dopasowywania przebiegu późniejszych wydarzeń do zachodzących zmian politycznych w regionie przyjęto datację na 530 rok. Biorąc pod uwagę propagandową wymowę panegiryku na cześć Amalasunty, a zwłaszcza wewnętrzną sprzeczność wywodów Kasjodora o stanie stosunków Ostrogotów z Justynianem, oraz moment opracowania tego utworu w siedem lat po śmierci Teodoryka, nie ma jakichkolwiek podstaw do przypuszczeń o nieoficjalnym udziale cesarstwa w walkach z Ostrogotami, które w interesie Justyniana jakoby mieli prowadzić w 530 roku Gepidzi i Herulowie ${ }^{26}$. Wobec złego stanu zachowania tekstu panegiryku Kasjodora z okazji małżeństwa Witigesa z Matasuntą równie bezpodstawne wydaje się eksponowanie wybitnej roli Witigesa jako dowódcy wojsk Ostrogotów w wojnie z Gepidami ${ }^{27}$.

O walkach Ostrogotów z Gepidami o Sirmium za rządów Amalasunty wspomina również Prokopiusz z Cezarei w początkowej części swego dzieła o wojnie Justyniana $\mathrm{z}$ Ostrogotami ${ }^{28}$. Według Prokopiusza wraz z pogorszeniem się stanu zdrowia Atalaryka pogłębiały się problemy Amalasunty z opozycją wśród arystokracji ostrogockiej $^{29}$. Zamierzając rozprawić się z nią, postarała się o poparcie Justyniana, który

${ }_{25}$ W najbardziej uznanych opracowaniach zdecydowanie dominuje datacja wojny na $530 \mathrm{r}$.: L. Schmidt, op. cit., s. 534; H. Wolfram, Die Geburt Mitteleuropas. Geschichte Österreichs vor seiner Entstehung 378-907, Wien 1987, s. 73; B. Rubin, Das Zeitalter Justinians, Bd. 2, Hrg. C. Capizzi, Berlin 1995, s. 75; W. Pohl, Gepiden, „RGA” 1998, 11, s. 133; F. Lotter (unter Mitarbeit von R. Bratož, H. Castritius), Völkerverschiebungen im Ostalpen-Mitteldonau-Raum zwischen Antike und Mittelalter (375-600), Berlin-New York 2003, s. 134; H. Wolfram, Historia Gotów, s. 380; M. Pańdura, op. cit..., s. 70; A. Sarantis, Military Encounters \& Diplomatic Affairs in the Northern Balkans, s. 767; idem, Justinian's..., s. 64, 455; G. Heydemann, The Ostrogothic Kingdom: Ideologies and Transitions [w:] A Companion..., s. 35. Warto zwrócić uwagę, że tego typu podejście nie ma nic wspólnego z informacjami źródeł, co zauważył J. Prostko-Prostyński, op. cit., s. 220, przyp. 25, s. 243 , przyp. 148 .

26 E. Stein, Histoire..., s. 307; F.E. Wozniak, Byzantine..., s. 144; idem, East Rome..., s. 377; B. Rubin, Das Zeitalter..., s. 75; Cassiodoro Variae..., s. 129; G. Hey demann, op. cit.

27 Powszechnie w literaturze przedstawia się Witigesa jako wodza w wojnie 530 r.: W. Ensslin, Witigis, RE 2A IX, Stuttgart 1961, kol. 395; L. Rübekeil, Witiges, „RGA” 2007, 34, s. 151. H. Wolfram, Historia Gotów, s. 389, 555 przyp. 10 i 11, początki kariery Witigesa odnosi do końca panowania Teodoryka na podstawie panegiryku Kasjodora, natomiast samodzielne dowództwo miał on sprawować w $530 \mathrm{r}$.

28 Omówienie stanu badań nad dorobkiem Prokopiusza: G. Greatrex, Perceptions of Procopius in resent scholarschip, „Histos” 2014, 8, s. 76-121; D. Brodka, Prokopiusz z Cezarei. Historia Wojen, t. 1, Kraków 2013, s. XX-CVI; M.R. Cataudella, Historiography in the East [w:] Greek \& Roman Historiography. Fourth to Sixth Century A. D., ed. G. Marasc o, Leiden-Boston 2003, s. 391-447.

${ }_{29}$ Procopii Caesariensis, Opera Omnia. De bellis libri VIII, vol. II, rec. J. Haury, add. et corr. G. Wirth, Lipsiae 1963, ks. V, 2, 1 - V 4, 4 (dalej skrót Prokopiusz, cyfry oznaczają kolejno: księgę „Wojen”, rozdział, ustęp). Komentarz - B. Rubin, Prokopios von Kaisareia, Stuttgart 1954, kol. 155158. Relacja Prokopiusza jest uwzględniana przy charakterystyce sytuacji w Italii w przededniu wojny 
zgodził się ją przyjąć, gdyby musiała ratować się ucieczkąa ${ }^{30}$ Cesarz, nie mając informacji o przebiegu wydarzeń i obawiając się o los królowej, postanowił wysłać do Rawenny posła w celu rozeznania sytuacji na tamtejszym dworze ${ }^{31}$. Oficjalnie miał on wyjaśnić wrogie działania Ostrogotów, którzy nie chcieli oddać cesarzowi twierdzy Lilybaeum na Sycylii, należącej do pokonanych przez niego Wandalów, przyjęli w Neapolu 10 dezerterów z wojsk w Afryce oraz zaatakowali rzymskie miasto Gracjanę $^{32}$. Właśnie wspominając incydent $\mathrm{z}$ tym ostatnim miastem, Prokopiusz pisze wprost o wojnie Ostrogotów z Gepidami w okolicach Sirmium:

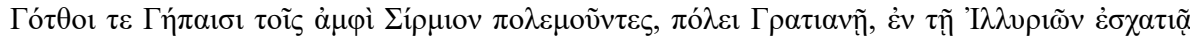

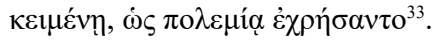

W odpowiedzi Amalasunta oficjalnie stwierdziła, że uderzenie na Gracjanę jej wojsk było dziełem przypadku i niewiedzy. Wypomniała cesarzowi pomoc, jakiej Ostrogoci udzielili mu w czasie wyprawy jego floty do Afryki przeciw Wandalom, a poufnie potwierdziła gotowość do przekazania mu władzy nad Gotami i Italikami ${ }^{34}$. Ze względu na wzmiankę o ataku Ostrogotów na należącą do cesarstwa Gracjanę, miejscowość położoną nad Dunajem na wschód od Singidunum ${ }^{35}$, można wskazać obszar, na którym toczyły się walki. Obejmował on prawdopodobnie rejon Sirmium, tzn. miasto z okolicznymi ziemiami aż do Dunaju. Nic więcej nie wiadomo o tym konflikcie, a kontekst, w jakim Prokopiusz umieścił tę opowieść, wskazuje, że miał

z Justynianem. Zwykle podkreśla się złożoną sytuację polityczną i silną opozycję przeciw Amalasuncie. $\mathrm{Z}$ jednej strony akcentuje się wpływy Ostrogotów ze sfer wojskowych domagających się od królowej wychowania syna $\mathrm{w}$ tradycyjny sposób, $\mathrm{z}$ drugiej zaś konflikt $\mathrm{z}$ arystokracją o bezprawne zagarnianie majątków, jak sprawa Teodahada: R. Mac Phers on, Cassiodorus' Variae in their literary and historical setting, Poznań 1989, s. 220-223, S. Krautschick, op. cit., s. 176-179, przyp. 17.

30 Uzgodniono, że w razie niebezpieczeństwa królowa miała się udać do Epidamnos, gdzie oczekiwał na nią okręt ze skarbem. Przypuszczalnie tego typu plany pojawiły się na początku $533 \mathrm{r}$. Prokopiusz V 2, 23-29; V 3, 10-14. - Regesten der Kaiserurkunden des Oströmischen Reiches von 476 bis 565, bearbeitet von T.C. Lounghis, B. Blysidu, St. Lampakes, Nicosia 2005 (Zyprisches Forschungszentrum. Quellen und Studien zur Geschichte Zyperns - LII), nr 989 (dalej Regesten).

31 Wysłanie Aleksandra - Prokopiusz V 3, 14 -15. Senator Aleksander był wcześniej posłem do Persji - J.R. Martindale, Alexander I, PLRE III a, s. 41-42.

32 Prokopiusz V 3, 15. Szczegóły opisu konfliktu Ostrogotów z Gepidami u Prokopiusza przesądzają, że zaistniał on u schyłku regencji Amalasunty. Tymczasem L.M. Hartmann, Geschichte..., s. 242, i H. Wolfram, Historia Gotów, s. 384, przyjmowali, że wspominał wcześniejsze wydarzenia.

33 Prokopiusz V 2, 15 (cytat za wydaniem: J. Haury, add. et corr. G. Wirth, Lipsiae 1963, s. 17, $8-11)$.

34 Oficjalna odpowiedź Amalasunty - Prokopiusz V 3, 19-28. Wątek tajnych negocjacji Prokopiusz V 3, 12 i 28.

35 Sama Gracjana była niewielkim ośrodkiem położonym nad Dunajem na wschód od Singidunum. Jak się wydaje, w okresie późnorzymskim posiadała status miasta, na co wskazuje wzmianka w dziele Hieroklesa: E. Honigmann, Le Synekdèmos d'Hiéroclès et l'Opuscule géographique de Georges de Chypre. Texte, introduction, commentaire et cartes („Corpus Bruxellense Historiae Byzantinae: Forma Imperii Byzantini”, 1), Bruxelles 1939, s. 21 (657, 4). O tym ośrodku V. Dintchev, The limit of urban life in the Late Antique dioceses of Thracia and Dacia: the overestimated centers, „Archaeologia Bulgarica” 2000, IV, s. 68-69. 
on miejsce w końcowym okresie rządów Amalasunty, a więc później niż działania opisane przez Kasjodora.

W dalszej relacji o przebiegu wojny w Italii Prokopiusz opisuje upadek skompromitowanego porażkami króla Teodahada i wybór przez Ostrogotów jego następcy Witigesa ${ }^{36}$. Podaje, że nowy król nie pochodził z możnego rodu, lecz cieszył się sławą wśród swoich zdobytą w walkach o Sirmium za Teodoryka Wielkiego ${ }^{37}$. W dotychczasowych badaniach generalnie odmawia się relacji Prokopiusza o walkach Ostrogotów z Gepidami samoistnego znaczenia i uwzględnia się ją tylko jako uzupełnienie rekonstrukcji konfliktu tych ludów i kariery Witigesa opartych na przekazie Kasjodora ${ }^{38}$. Tego typu podejście nie wydaje się słuszne i co ważniejsze, nie zostało poparte odpowiednią argumentacją. Analiza przekazu Prokopiusza wskazuje $\mathrm{z}$ jednej strony na jego dobrą orientację $\mathrm{w}$ wydarzeniach odnoszących się do spraw politycznych i militarnych mających związek z wojną Justyniana w Italii, z drugiej zaś na jego brak zainteresowania sytuacją na obszarach naddunajskich ${ }^{39}$. W związku z tym najbardziej prawdopodobne jest przyjęcie, że nie pomylił wojen o Sirmium, lecz podał informacje dotyczące konfliktu Ostrogotów z Gepidami mające związek z tym, o czym pisał swe dzieło, czyli wojną Justyniana z Ostrogotami. Równie prawdopodobne jest, że dane o pochodzeniu i zasługach Witigesa są wiarygodne. Prokopiusz zamieścił je zapewne w takim kontekście, w jakim je poznał, tzn. przy okazji przedstawienia nowego króla, a nie sytuacji w regionie naddunajskim czy z powodu konfliktu o Sirmium.

Fakty podane przez Prokopiusza o pochodzeniu i karierze Witigesa doskonale korespondują z jego ogólnym opisem sytuacji wewnętrznej wśród Ostrogotów. Za nominalnych rządów Atalaryka doszło wśród możnych do poważnego podziału na zwolenników i przeciwników Amalasunty, która nie cofnęła się przed represjami. Teodahad również nie wahał się pozbyć królowej i ukarać śmiercią jej zwolenników,

36 Prokopiusz V 11, 5-9. W. Ensslin, Witigis, kol. 395; L. Rübekeil, op. cit., s. 151. Upadek Teodahada - M. Vitiello, op. cit., s. 157-163.

${ }^{37} \mathrm{~W}$ związku z tą relacją pojawiają się hipotezy, że Prokopiusz traktował wojny Ostrogotów z Gepidami z 504 i 530 r. jako jedną: W. Poh1, Die Gepiden und die Gentes..., s. 289, bądź pomylił wojnę z 504 r. z działaniami z 530 r. - H. Wolfram, Historia Gotów, s. 548, przyp. 108. A. Sarantis, Justinian's..., s. 62, przyjmuje, jakoby Prokopiusz mógł się nie orientować w sytuacji, bo przebywał w Afryce i podawał informacje $\mathrm{z}$ drugiej ręki.

38 Łącząc informacje Kasjodora i Prokopiusza jako opis jednej wojny, przyjmuje się, że miała ona miejsce w latach od 527 do 530. Inaczej tylko J. Prostko-Prostyński, op. cit., s. 220, przyp. 25, s. 243 , przyp. 148 .

39 O wojnie obu ludów w początkach rządów Amalasunty za małoletniości Atalaryka zapewne w ogóle nie wiedział, bo miała charakter lokalny, związany z sytuacją w Illyricum. W tej części dzieła Prokopiusz pisze niewiele o wydarzeniach na Bałkanach: S. Turlej, Bałkany w cieniu wojen Justyniana? Znaczenie relacji Prokopiusza [w:] Hortus Historiae. Księga pamiątkowa ku czci profesora Józefa Wolskiego w setna rocznicę urodzin, red. E. Dąbrowa, M. Dzielska, M. Salamon, S. Sprawski, Kraków 2010, s. 707-722. Dla późniejszych wydarzeń rozgrywających się w Illyricum mógł wykorzystać źródła ustne: D. Brodka, Prokop von Keisareia und seine Informanten, „Historia” 2015, 65, s. 108-124. Prokopiusz nie miał jakiegokolwiek powodu, by przeinaczyć fakty, ponieważ były to sprawy „neutralne” z jego punktu widzenia. Zaistniały w przeszłości i z perspektywy aktualnych rozgrywek politycznych w kręgach władzy w Konstantynopolu nie miały znaczenia - przyp. 23. 
a i później wyraźnie deklarował poparcie dla jej wrogów ${ }^{40}$. Pełnienie jakiejkolwiek wysokiej funkcji urzędniczej, nie mówiąc o naczelnym dowództwie nad armią walczącą o Sirmium za rządów Amalasunty, oznaczało dla Witigesa opowiedzenie się po jednej ze stron konfliktu i narażenie się na nienawiść jej wrogów. W takiej sytuacji powierzenie przez Teodahada dowództwa Witigesowi, czyli znanej i ważnej osobistości przy Amalasuncie, wydaje się również wykluczone. Wybór przez Ostrogotów Witigesa na króla wydaje się w pełni zrozumiały, jeśli pamiętano o jego dzielnej postawie w walkach o Sirmium za Teodoryka, a on sam nie skompromitował się za rządów Amalasunty i Teodahada ${ }^{41}$. Dane Prokopiusza o karierze Witigesa doskonale uzupełniają zachowane wzmianki u Kasjodora, jeśli znaczenia tych ostatnich się nie wyolbrzymia ${ }^{42}$.

Opierając się na analizie relacji Prokopiusza, można precyzyjnie określić chronologię walk o Sirmium, o których wspomniał. Poselstwo senatora Aleksandra o takim zakresie spraw do załatwienia, jak roszczenia do twierdzy Lilybaeum na Sycylii, przyjęcie dezerterów z wojsk w Afryce i atak na rzymskie miasto Gracjanę, mogło wyruszyć z Konstantynopola do Italii przypuszczalnie latem $534 \mathrm{roku}^{43}$. Za taką datacją przemawia długi przebieg sporu o twierdzę Lilybaeum u Prokopiusza. Belizariusz po pokonaniu Wandalów postanowił ją zająć i gdy się to nie udało, wystąpił na piśmie do dowódców Ostrogotów. Ci z kolei zwrócili się do Amalasunty, a królowa

40 Zgładzenie wrogów przez Amalasuntę - Prokopiusz V 2,25. W trzech różnych miejscach jego relacji pojawiają się informacje o wrogach królowej i poparciu Teodahada dla nich - Prokopiusz V 4, 13; V 4, 26-27 i V 4, 31.

${ }^{41}$ Jak wynika ze źródeł, Teodoryk cieszył się dobrą opinią nie tylko wśród Ostrogotów - A. Goltz, Barbar - König - Tyrann: Das Bild Theoderichs des Großen in der Überlieferung des 5. bis 9. Jahrhunderts, Berlin-New York 2008, szczególnie s. 300-303; T. Woliń s k a, A Barbarian as Incarnation of Roman Virtues? Theodoric the Great in Byzantine and Italian Sources [w:] Within the Circle of Ancient Ideas and Virtues. Studies in Honour of Professor Maria Dzielska, ed. K. Tw ardow ska, M. Salamon, S. Sprawski, M. Stachura, S. Turlej, Kraków 2014, s. 411-421. Ukazywanie w taki sposób źródeł popularności Witigesa wydaje się przekonujące i Prokopiusz mógł podać wiarygodne informacje. Sam Witiges powoływał się na Teodoryka i tradycję plemienną, co przekazał Kasjodor: M. Vitiello, Motive germanischer Kultur und Prinzipien des gotischen Königtums im Panegyricus des Ennodius an Theoderich den Grossen (Die Drei „,directen Reden”), „Hermes” 2005, 133, s. 110; R. Kasperski, Teodoryk Wielki i Kasjodor, Kraków 2013, s. 247-248.

42 Nic nie stoi na przeszkodzie, zwłaszcza wiek, by przyjąć udział Witigesa w walkach o Sirmium zarówno w 504 r., jak i po śmierci Teodoryka - J.R. Martindale, Vitiges, op. cit., s. 1382; A. S arantis, War and Diplomacy..., s. 21-22. Pochodzenie Witigesa nie było niskie, biorąc pod uwagę rolę w armii jego krewnych. Może lepiej mówić, że nie należał do elity arystokratycznej - D. Clau de, Die ostogotischen Königserhebungen [w:] H. Wolfra m, F. Daim, Die Völker..., s. 166, p. 142.

43 Wysłanie poselstwa Aleksandra - Prokopiusz V 3, 14-15. Jest ono datowane rozbieżnie na $533 \mathrm{r}$. lub lato $534 \mathrm{r}$. - Regesten $\mathrm{nr} 1005$. W literaturze pojawiają się problemy z uporządkowaniem informacji o poselstwach Justyniana do Amalasunty i trzeba zwrócić uwagę na niekonsekwencje w interpretacji, np.: T.C. Lounghis, Les Ambassades byzantines en Occident depuis la formation des états barbars jusqu'aux croisades (407-1096), Athènes 1980, s. 64-65 - oficjalne poselstwo Aleksandra i jego powrót z biskupami w 534 r. do Konstantynopola. Z kolei w zestawieniu poselstw (op. cit., s. 464-465) pod datą 533 r. pojawia się informacja o poselstwie do papieża Jana II biskupów Hypacjusza i Demetriusza oraz również pod 533 r. poselstwo senatora Aleksandra do Amalasunty. Potem wspomniano już tylko poselstwo z 534 r. Piotra Patrycjusza. Omawiam ten problem w innym miejscu - przyp. 23. 
odpowiedziała wodzowi i wtedy dopiero sprawę przekazano cesarzowi ${ }^{44}$. Justynian podzielił pogląd Belizariusza w sprawie Lilybaeum i wydał zalecenia Aleksandrowi. Ten dotarł do Rawenny i otrzymał odpowiedź od królowej, jak wynika z jej treści, jeszcze za życia Atalaryka, czyli przed 2 października 534 roku$^{45}$. Można zatem przyjąć, że gdy wojska Ostrogotów wtargnęły na ziemie cesarstwa i zaatakowały Gracjanę, to informacje o tym dotarły do Justyniana przed wysłaniem poselstwa Aleksandra ${ }^{46}$. Z kolei Kasjodor objął stanowisko prefekta pretorium Italii 1 września 533 roku i prawdopodobnie niedługo po tej dacie napisał wspomniany list do sena$\mathrm{tu}^{47}$. Nie ma w nim żadnej aluzji do czasów współczesnych poświadczającej trwanie konfliktu zbrojnego z Gepidami. Biorąc to pod uwagę, można z dużym prawdopodobieństwem wojnę Ostrogotów z Gepidami opisaną przez Prokopiusza datować na okres jesień 533 - lato 534 roku $^{48}$. Główne działania wojenne Ostrogotów przeciw Gepidom zapewne miały miejsce przy sprzyjających warunkach pogodowych od wiosny 534 roku.

Odczytując dosłownie informacje Kasjodora i Prokopiusza na temat stosunków Ostrogotów z Gepidami w latach 526-535, najbardziej prawdopodobne wydaje się zaistnienie dwóch konfliktów zbrojnych między tymi ludami. Oba były zwycięskie dla Ostrogotów i pozwoliły im utrzymać Sirmium z okolicznymi ziemiami aż do Dunaju. Przypuszczalnie pierwsza wojna rozpoczęła się niedługo po śmierci Teodoryka,

44 Sprawa roszczeń do Lilybaeum zaczęła się na przełomie 533 r. i 534 r. - Prokopiusz IV 5, 11 25; E. Chrysos, Die Amaler - Herrschaft in Italien. Der Vertragsentwurf des Jahres 535, „Byzantion” 1981, 51, s. 436; J. Strzelczyk, Wandalowie i ich afrykańskie państwo, Warszawa 1992, s. 145, 160, 197; T. Wolińska, Sycylia w polityce Cesarstwa Bizantyńskiego w VI-IX w., Łódź 2005, s. 35-36. Porozumienie Teodoryka z Thrasamundem i przekazanie Wandalom Lilybaeum: M. Wilczyński, Zagraniczna i wewnętrzna polityka afrykańskiego państwa Wandalów, Kraków 1994, s. 85-86.

45 Poselstwo Aleksandra i odpowiedź Amalasunty - Prokopiusz V 3, 17-18 i V 3, 19-27. Z relacji Prokopiusza wynika, że gdy królowa udzielała odpowiedzi Justynianowi, żył Atalaryk Prokopiusz V 3, 19. Według takiej interpretacji danych Prokopiusza datację poselstwa na połowę 534 r. przyjmował H. Koh1, op. cit., s. 41, przyp. 102. Na lato 534 r.: H. Wolfram, Historia Gotów, s. 384; J.R. Martindale, Alexander I, op. cit., s. 42.

46 Prokopiusz, podając szczegóły na temat poselstwa Aleksandra, połączył jego misję z poselstwem biskupów Hypacjusza i Demetriusza do papieża. Szczegółowe omówienie tego ostatniego poselstwa i ówczesnej polityki religijnej Justyniana: M.V. An astos, Justinian's despotic control over the Church as illustrated by his edicts on the theopaschite formula and his letter to pope John II in 533, „Zbornik Radova Vizantološkog Instituta" 1964, 8/2, s. 1-11; M. Meier, Das andere ..., s. 215-223. Tymczasem, jak się wydaje, poselstwo Aleksandra dotyczące m.in. Gracjany miało miejsce później. Problem z datacją omawiam w innym miejscu - przyp. 23.

47 Nominacja: Kasjodor, Variae IX 24-25. Objęcie przez Kasjodora stanowiska prefekta 1 września 533 r. - Th. Mommsen, Prooemium [w:] Cassiodorus, Variae, s. XXX; J.R. Martindale, Fl. Magnus..., s. 267; L.M. Hartman n, Cassiodorus 4, kol. 1673. Datacja listu na krótko po 1 września 533 r. - S. Krautschick, op. cit., s. 13, 96 przyp. 2, 105, 108; J. Prostko-Prostyński, s. 242. Zaraz po objęciu stanowiska - J.J. O ' D on ne11, Cassiodorus, Berkeley CA 1979, s. 64. Nie wiadomo, na jakiej podstawie datacja na początek 534 r. - A. Sarantis, War and Diplomacy..., s. 21; idem, Justinian's..., s. 63 , przyp. 237.

48 Wojnę na lata 534-535 datował J. Prostko-Prostyński, op. cit., s. 220, przyp. 25. Z relacji Prokopiusza wynika, że gdy Amalasunta udzielała odpowiedzi Justynianowi, żył Atalaryk - Prokopiusz V 3, 19. 
gdy Amalasunta obejmowała władzę, co znajduje potwierdzenie w obu wzmiankach Kasjodora. Jakkolwiek brakuje bezpośrednich informacji o tym, jak długo trwała, to brak o niej jakichkolwiek wzmianek przy opisie wydarzeń z lat 528-530 dowodzi, że przypuszczalnie zakończyła się już w $527 \mathrm{roku}^{49}$. Druga wojna toczyła się prawdopodobnie najwcześniej od końca 533 do lata 534 roku. Tylko przyjmując taki scenariusz rozwoju sytuacji nad środkowym Dunajem w latach 526-535, można interpretować źródła mówiące o walkach o Sirmium dosłownie i zrozumieć całkowitą bierność Ostrogotów na zachodnich rubieżach ich państwa wobec ekspansji Franków ${ }^{50}$.

\section{BIBLIOGRAFIA}

Anastos M.V., Justinian's despotic control over the Church as illustrated by his edicts on the theopaschite formula and his letter to pope John II in 533, „Zbornik Radova Vizantološkog Instituta" 1964, 8/2, s. 1-11.

Arnold J.J., Theoderic and the Roman Imperial Restoration, Cambridge 2014.

Bajoni M.G., À propos d'une lettre diplomatique: Cassiodore, Variae I,1, „Latomus” 2015, 74, s. 493-497.

Barišić F., Vizantiski Singidunum, „Zbornik Radova Vizantološkog Instituta” 1953, 3, s. $1-14$.

Bjornlie M.S., Politics and Tradition between Rome, Ravenna and Constantinople. A Study of Cassiodorus and the Variae, 527-554, Cambridge 2013.

Bóna I., Das Anbruch Mittelaters. Gepiden und Langobarden im Karpatenbecken, Budapest 1976.

Brodka D., Prokop von Keisareia und seine Informanten, „Historia” 2015, 65, s. 108-124.

Brodka D., Prokopiusz z Cezarei. Historia Wojen, t. 1, Kraków 2013.

Caldwell III C.D., The Balkans [w:] The Oxford Handbook of Late Antiquity, Oxford 2012, s. 92-114.

Cardini F., Cassiodoro il Grande. Roma i barbarii e il monachsimo, Milano 2009.

49 Najbardziej prawdopodobne wydaje się szybkie pokonanie Gepidów i zakończenie walk już w 527 r. Źródła bizantyńskie podają stosunkowo sporo informacji na temat sytuacji na obszarach naddunajskich w latach 528-530 za sprawą pozyskania przez cesarza Justyniana Herulów i Mundusa. Jeżeli wizyta króla Herulów Grepesa (J.R. Martindale, Grepes, PLRE III a, s. 555) w Konstantynopolu związana z jego chrztem miała miejsce 6 stycznia 528 r., to poprzedzały ją zapewne negocjacje i zabiegi dyplomatyczne. Milczenie źródeł bizantyńskich na temat walk o Sirmium po śmierci Teodoryka uprawdopodabnia nie tylko, że szybko się skończyły, lecz także ograniczenie ich zasięgu do ziem odległych od posiadłości cesarstwa i udział w wojnie jedynie Ostrogotów i Gepidów, bez zaangażowania cesarstwa.

50 Pod koniec panowania Teodoryka Wielkiego widać duże zaangażowanie tego władcy w zabezpieczenie posiadłości Ostrogotów przed Frankami: W. En s s lin, Theoderich der Grosse, München 1959, s. 305-331; J. Moorhaed, Theoderic in Italy, Oxford 1992, s. 212-251; G. Hals a11, Barbarian Migrations and the Roman West 376-568, Oxford 2007, s. 291-293. Ustępstwa Amalasunty wobec Franków i unikanie konfliktu zbrojnego: H. Wolfram, Historia Gotów, s. 381. Oficjalna wypowiedź Kasjodora w imieniu Amalasunty na temat ówczesnych stosunków z Frankami i Burgundami - przyp. 10. 
Cassiodori Orationvm Reliqviae, ed. L. Traube, Monumenta Germaniae Historica. Auctores Antiquissimi, T. XII, Berolini 1894, s. 473-484.

Cassiodori senatoris variae, ed. Th. Mommsen, Monumenta Germaniae Historica. Auctores Antiquissimi, T. XII, Berolini 1894, s. 327-330.

Cassiodoro Variae. Vol. 5: Libri XI, XII, Direzione di A. Gardina. A cura di A. Gardina, G. Cecconi e I. Tantillo, Roma 2015.

Cataudella M.R., Historiography in the East [w:] Greek \& Roman Historiography. Fourth to Sixth Century A. D., ed. G. Marasco, Leiden-Boston 2003, s. 391-447.

Chrysos E., Die Amaler - Herrschaft in Italien. Der Vertragsentwurf des Jahres 535, „Byzantion” 1981, 51, s. 430-474.

Claude D., Die ostogotischen Königserhebungen [w:] H. Wolfram, F. Daim, Die Völker an der Mitteren und Unteren Donau im Fünften und Sechsten Jahrhundert, Österreichische Akademie der Wissenschaften, Philosophisch-Historische Klasse, Denkschriften 145, Wien 1980, s. 149-186.

A Companion to Ostrogothic Italy, Leiden, eds. J.J. Arnold, M.S. Bjornlie, K. Ses sa, Brill, Leiden-Boston 2016.

Cooper K., The heroine and the historian: Procopius of Caesarea on the troubled reign of Queen Amalasuentha [w:] A Companion to Ostrogothic Italy, Leiden, eds. J.J. Arnold, M.S. Bjornlie, K. Sessa, Brill, Leiden-Boston 2016, s. 296-315.

Curta F., The Making of the Slavs. History and Archaeology of the Lower Danube Region, c. 500-700, Cambridge 2001.

Curta F., Tworzenie Stowian. Powrót do stowiańskiej etnogenezy [w:] Nie-Stowianie o początkach Słowian, red. P. Urbańczyk, Poznań-Warszawa 2006, s. 27-55.

Dintchev V., Classification of the Late Antique cities in the dioceses of Thracia and Dacia, „Archaeologia Bulgarica” 1999, III, s. 39-73.

Dintchev V., The limit of urban life in the Late Antique dioceses of Thracia and Dacia: the overestimated centers, „Archaeologia Bulgarica” 2000, IV, s. 65-84.

Ensslin W., Theoderich der Grosse, München 1959.

Ensslin W., Witigis, Realencyclopädie der Classischen Altertumswissenschaft 2A IX, Stuttgart 1961, kol. 395-400.

Fauvinet-Ranson V., Portrait d'une regente: un panegyrique d'Amalasonthe (Cassiodorus, Variae XI.1), „Cassiodorus” 1998, 4, s. 267-308.

Giardina A., Cassiodoro politico, Roma 2006.

Gillett A., The purposes of Cassiodorus' Variae' [w:] After Rome's Fall: Narrators and Sources of Early Medieval History, ed. A. Murray, Toronto 1998, s. 37-50.

Goltz A., Barbar-König - Tyrann: Das Bild Theoderichs des Großen in der Überlieferung des 5. bis 9. Jahrhunderts, Berlin-New York 2008, szczególnie s. 300-303.

Gračanin H., The Huns and South Pannonia, „Byzantinoslavica” 2006, LXIV, s. 29-76.

Gračanin H., Škargulja J., The Ostrogoths in the Late Antique Southern Pannonia, „Acta Archaeologica Carpathica" 2014, XLIX, s. 165-205.

Greatrex G., Perceptions of Procopius in resent scholarschip, „Histos” 2014, 8, s. 76-121. Haarer F., Anastasius I. Politics and Empire in the Later Roman World, Cambridge 2006.

Halsall G., Barbarian Migrations and the Roman West 376-568, Oxford 2007.

Hartmann L.M., Cassiodorus 4 [w:] Realencyclopädie der Classischen Altertumswissenschaft, III, Stuttgart 1899, kol. 1672-1676.

Hartmann L.M., Geschichte Italiens im Mittelalter, Bd. I, Gotha 1897.

Haupt M., Bruchstück einer Lobrede auf den König Theodahad, „Hermes” 1873, 7, s. 377379. 
Heather P., Odrodzenie Rzymu. Cesarze i papieże: bój o władzę nad chrześcijaństwem, przeł. J. Szczepański, Poznań 2014.

Heydemann G., The Ostrogothic Kingdom: Ideologies and Transitions [w:] A Companion to Ostrogothic Italy, eds. J.J. Arnold, M.S. Bjornlie, K. Sess a Leiden, Brill, LeidenBoston 2016, s. 17-46.

Hodgkin T., Italy and Her Invaders, Oxford 1896, vol. III, Book IV.

Honigmann E., Le Synekdèmos d'Hiéroclès et l'Opuscule géographique de Georges de Chypre. Texte, introduction, commentaire et cartes („Corpus Bruxellense Historiae Byzantinae: Forma Imperii Byzantini”, 1), Bruxelles 1939.

Kakridi C., Cassiodors „Variae”. Literatur und Politik im ostrogotischen Italien, Leipzig 2005.

Kasjodor Senator, Variae (I-XII), przekład A. Kołtunowska, R. Sawa, rewizja przekładu i opracowanie M. Ożóg, H. Pietras, Kraków 2017.

Kasperski R., Teodoryk Wielki i Kasjodor, Kraków 2013.

Kohl H., Zehn Jahre ostgotischer Geschichte, vom Tode Theoderich's des Grossen bis zur Erhebung des Vitigis, Leipzig 1877.

Krautschick S., Cassiodor und die Politik seiner Zeit, Bonn 1983.

Lotter F. (unter Mitarbeit von R. Bratož, H. Castritius), Völkerverschiebungen im Ostalpen-Mitteldonau-Raum zwischen Antike und Mittelalter (375-600), Berlin-New York 2003.

Lounghis T.C., Les Ambassades byzantines en Occident depuis la formation des états barbars jusqu' aux croisades (407-1096), Athènes 1980.

MacPherson R., Cassiodorus'Variae in their literary and historical setting, Poznań 1989.

Martindale J.R., The Prosopography of the Later Roman Empire, vol. II, Cambridge 1980.

Martindale J.R., The Prosopography of the Later Roman Empire, vol. IIIa-IIIb, Cambridge 1992.

Meier M., Anastasios I. Die Entstehung des Byzantinischen Reiches, Stuttgart 2009.

Meier M., Das andere Zeitalter Justinians, Göttingen 2003.

Mirković M., Sirmium - its history from the I century A. D. to 582 A.D., Sirmium I: Archaeological Investigations in Syrmian Pannonia, ed. V. Popović, Belgrad 1971, s. 5-90.

Moorhaed J., Theoderic in Italy, Oxford 1992.

O’Donnell J.J., Cassiodorus, Berkeley, CA 1979.

Pańdura M., Ardarici gladius. Historia Królestwa Gepidów, „Slavia Antiqua” 2004, XLV, s. 55-88.

Pohl W., Gepiden, „Reallexikon der Germanischen Altertumskunde” 1998, 11, s. 115-140.

Pohl W., Die Gepiden und die Gentes an der mitteren Donau nach dem Zerfall des Attilareiches [w:] H. Wolfram, F. Daim, Die Völker an der Mitteren und Unteren Donau im Fünften und Sechsten Jahrhundert, Österreichische Akademie der Wissenschaften, Philosophisch-Historische Klasse, Denkschriften 145, Wien 1980, s. 239-305.

Procopii Caesariensis, Opera Omnia. De bellis libri VIII, vol. I-II, rec. J. Haury, add. et corr. G. Wirth, Lipsiae 1962-1963.

Prostko-Prostyński J., Utraeque Res Publicae. The Emperor Anastasius I’s Gothic Policy (491-518), Poznań 1994,

Regesten der Kaiserurkunden des Oströmischen Reiches von 476 bis 565, bearbeitet von T.C. Lounghis, B. Blysidu, St. Lampakes, Nicosia 2005.

Rübekeil L., Witiges, „Reallexikon der Germanischen Altertumskunde” 2007, 34, s. 150 153.

Rubin B., Prokopios von Kaisareia, Stuttgart 1954. 
Rubin B., Das Zeitalter Justinians, Bd. 2, Hrg. C. Capizzi, Berlin 1995.

Sarantis A., Justinian's Balkan Wars. Campaigning, Diplomacy and Development in Illyricum, Thrace and the Northern World A.D. 527-565, Prenton 2016.

Sarantis A., Military Encounters \& Diplomatic Affairs in the Northern Balkans, „Late Antique Archaeology" 2011, 8.2, Brill, Leiden-Boston 2013, s. 764-807.

Sarantis A., War and Diplomacy in Pannonia and the Northwest Balkans during the reign of Justinian. The Gepid Threat and Imperial Responses, „Dumbarton Oaks Papers” 2009, 63, s. $15-40$.

Schmidt L., Die Ostgermanen, München 1941.

Stein E., Histoire du Bas-Empire, t. II, Paris-Bruxelles-Amsterdam 1949.

Stein E., Untersuchungen zur spätrömische Verwaltungsgeschichte, „Rheinisches Museum für Philologie" 1925, 74, s. 347-394.

Strzelczyk J., Wandalowie i ich afrykańskie państwo, Warszawa 1992.

Turlej S., Batkany w cieniu wojen Justyniana? Znaczenie relacji Prokopiusza [w:] Hortus Historiae. Księga pamiątkowa ku czci profesora Józefa Wolskiego w setna rocznice urodzin, red. E. Dąbrowa, M. Dzielska, M. Salamon, S. Sprawski, Kraków 2010, s. 707-722.

Turlej S., Herulian Settlements in Byzantium under Emperors Anastasius and Justinian, „Electrum” 2013, 20, s. 163-176.

Turlej S., Justynian i początki Stowian. Uwagi na temat teorii Florina Curty, „Zeszyty Naukowe Uniwersytetu Jagiellońskiego, Prace Historyczne”, z. 137, pod red. A. Patka, 2010, s. 11-19.

Turlej S., Justyniana Prima. Niedoceniany aspekt polityki kościelnej Justyniana, Kraków 2011.

Vitiello M., Cassiodorus anti-Boethius?, „Klio” 2008, 90, s. 462-484.

Vitiello M., Motive germanischer Kultur und Prinzipien des gotischen Königtums im Panegyricus des Ennodius an Theoderich den Grossen (Die Drei „,directen Reden”), „Hermes" 2005, 133, s. 100-115.

Vitiello M., Theodahad: A Platonic King at the Collapse of Ostrogothic Italy, Toronto 2014.

Vössing K., Sirmium, „Reallexikon der Germanischen Altertumskunde” 2005, 28, s. 499502.

Wilczyński M., Zagraniczna i wewnętrzna polityka afrykańskiego państwa Wandalów, Kraków 1994.

Wolfram H., Die Geburt Mitteleuropas. Geschichte Österreichs vor seiner Entstehung 378-907, Wien 1987.

Wolfram H., Historia Gotów, przeł. R. Darda-Staab, I. Dębek, K. Berger, WarszawaGdańsk 2003.

Wolińska T., A Barbarian as Incarnation of Roman Virtues? Theodoric the Great in Byzantine and Italian Sources [w:] Within the Circle of Ancient Ideas and Virtues. Studies in Honour of Professor Maria Dzielska, ed. K. Twardowska, M. Salamon, S. Sprawski, M. Stachura, S. Turlej, Kraków 2014, s. 411-421.

Wolińska T., Sycylia w polityce Cesarstwa Bizantyńskiego w VI-IX w., Łódź 2005.

Wozniak F.E., Byzantine Diplomacy and the Lombard - Gepidic Wars, „Balkan Studies” 1979, 20, s. 139-158.

Wozniak F.E., East Rome, Ravenna and Western Illyricum: 454-536, „Historia” 1981, 30, s. 351-382. 